\title{
PROFIL SUPPLEMENTARY SCALES MINNESOTA MULTIPHASIC PERSONALITY INVENTORY-2 (MMPI-2) ADAPTASI INDONESIA PADA MAHASISWA SEMESTER 1 TAHUN AKADEMIK 2013/2014 FAKULTAS KEDOKTERAN UNIVERSITAS SAM RATULANGI MANADO
}

\author{
Heidy Palempung \\ L. F. J. Kandow \\ B. H. R. Kairupan \\ ${ }^{1}$ Kandidat Skripsi Fakultas Kedokteran Universitas Sam Ratulangi Manado \\ ${ }^{2}$ Bagian Psikiatri Fakultas Kedokteran Universitas Sam Ratulangi
}

\begin{abstract}
College student as social beings confronted with a lot of exterbal or internal demandings. All the demands can be problematic, either it's academic nor non academic. It requires subtantial adjusments in the life of someone who is not accustomed to the status of a college student. This research aim to was to conduct a mental status examination to college student as early detection of mental disorders. This research is a cross-sectional survey study to determine the mental status of the first semester students of Medical Faculty of Sam Ratulangi University school year 2013/2014 based on supplementary scales. Instruments used were the Indonesian adaptation of MMPI-2. Sample distribution obtained from 101 respondents by socio-demographic majority in female (72,22\%), age 18 $(85,71 \%)$, origin from North Sulawesi (51,58\%), most tribe originating from North Sulawesi $(51,8 \%)$, parents working as private sector workers (45,24\%). Supplementary scales MMPI-2 distribution, scales obtained with a high precentage of succesion to the low: Mt (25,74\%), A (21,78\%), PK (20,19\%), Ho (11,88\%), AAS (9,9\%), MDS (7,92\%), Do (5,94\%), MAC-R (5,94\%), R (1,98\%), Re $(0,99 \%)$, dan $\mathrm{OH}(0,99 \%)$. Conclusion: From the results above the scales that found high are College Maladjustment Scales, Anxiety Scales, Post-Traumatic Stress Disorder Scales, and Hostility Scales. Scales for students who demonstrate a high yield should receive attention from faculty leaders to prevent the onset of mental disorders.
\end{abstract}

Keyword: Profile, supplementary scaless, MMPI-2, college student.

\begin{abstract}
Abstrak: Mahasiswa sebagai makhluk sosial hampir selalu diperhadapkan dengan banyak tuntutan eksternal atau internal. Banyaknya tuntutan dapat menimbulkan masalah akademis maupun nonakademis. Dibutuhkan penyesuaian yang besar dalam kehidupan seseorang yang belum terbiasa dalam menyandang status mahasiswa. Tujuan dari penelitian ini untuk melakukan pemeriksaan status mental pada mahasiswa sebagai deteksi dini adanya gangguan mental. Penelitian ini merupakan penelitian survey potong lintang untuk mengetahui status mental mahasiwa semester 1 TA 2013/2014 FK UNSRAT berdasarkan supplementary scales. Instrumen yang digunakan adalah MMPI-2 adaptasi Indonesia. Didapatkan distribusi mahasiswa dari 101 responden berdasarkan sosio-demografik terbanyak pada perempuan (72,22\%), umur 18 tahun (85,71\%), asal daerah berasal dari Sulawesi Utara (51,58\%), suku terbanyak berasal dari luar sulawei utara (51,8\%), pekerjaan orang tua sebagai pekerja swasta (45,24\%). Distribusi supplementary scales MMPI-2, didapatkan skala yang tinggi dengan presentase berturut-turut dari tinggi ke rendah yaitu: Mt (25,74\%), A (21,78\%), PK (20,19\%), Ho (11,88\%), AAS (9,9\%), MDS (7,92\%), Do (5,94\%), MAC-R (5,94\%), R (1,98\%), Re (0,99\%), dan $\mathrm{OH}(0,99 \%)$. Simpulan: Dari hasil di atas ditemukan skala yang tinggi yaitu College Maladjustment Scales, Anxiety Scales, Post-Traumatic Stress Dissorder Scales, dan Hostility Scales. Bagi mahasiswa yang skalanya menunjukkan hasil yang tinggi seharusnya mendapat perhatian dari pimpinan fakultas untuk mencegah timbulnya gangguan jiwa.
\end{abstract}

Kata Kunci: Profil, supplementary scales, MMPI-2, mahasiswa. 
Mahasiswa sebagai makhluk sosial hampir selalu diperhadapkan dengan banyak tuntutan eksternal dan atau internal yang dapat menimbulkan masalah-masalah akademis maupun non-akademis. Masalahmasalah akademis terutama disebabkan oleh ketidakmampuan untuk menyesuaikan diri dengan tuntutan studi sedangkan permasalahan non-akademis terutama berasal dari tekanan sosial yang dialami mahasiswa sehari-hari seperti permasalahan yang terkait ketegangan dengan keluarga, kesulitan biaya, kekurangan fasilitas belajar, dan konflik dalam pergaulan. ${ }^{1}$

Erick Erikson mengemukakan bahwa manusia sebagai makhluk individual sejak lahir hingga dewasa memiliki 8 stadium perkembangan kepribadian. Mahasiswa termasuk dalam stadium intimacy versus selfabsorbtion or isolation dimana pada tahap ini timbul dorongan untuk bersosialisasi seperti berhubungan baik dengan orangorang tertentu berupa kerjasama, cinta, ataupun persahabatan. Maka sangat diperlukan penyesuaian diri maupun penyesuaian sosial. Jika terjadi kegagalan dalam penyesuaian diri, maka dapat menimbulkan sikap maladaptif. Berawal dari sikap maladaptif inilah terjadi kegagalan seperti kenakalan/pemberontakan dan perilaku menyimpang seperti cuek, terlalu bebas karena merasa tidak tergantung pada orang lain. Selama stadium ini konflik psikososial yang penting dapat terjadi jika seseorang tidak dapat berinteraksi baik dengan lingkungannya. ${ }^{3,4}$ Gangguan mental sering memiliki onset pertama sesaat sebelum atau selama masa kuliah dengan rentang usia yang khas (18-24 tahun). ${ }^{5}$

Menurut data dari Badan Kesehatan Dunia (WHO) tahun 2000 angka gangguan mental yang semula $12 \%$ meningkat menjadi 13\% di tahun 2001 bahkan diperkirakan angka gangguan jiwa penduduk dunia akan meningkat hingga 15\% pada tahun 2015. ${ }^{6}$ Penelitian yang dilakukan pada mahasiswa kedokteran oleh Thomas Schwenk di Universitas Michigan America pada tahun 2010 menunjukan 53\% mahasiswa kedokteran mengalami gejala depresi level tinggi. ${ }^{7}$ Di Indonesia, sebesar $12 \%$ menunjukkan gejala kecemasan yang cukup tinggi menurut survei yang dilakukan oleh Anisah tahun 2012 pada 217 responden mahasiswa, dan dalam penelitian yang dilakukan oleh Pratiwi dari 194 responden mahasiswa terdapat sekitar $40 \%$ menunjukkan gejala-gejala depresi. Penelitianpenelitian ini sejalan dengan analisis yang dilakukan Utami tahun 2011 pada layanan konsultasi psikologi di Gadjah Mada Medical Center (GMC), mahasiswa yang dilayani menunjukkan masalah-masalah terkait dengan perasaan kurang bersemangat, tertekan, gangguan konsentrasi, perasaan bingung, kesulitan tidur, putus asa, dan dorongan mengakhiri hidup, bahkan pada beberapa kasus telah terjadi percobaan bunuh diri. $^{8}$

Melihat kenyataan di atas maka sangat penting untuk melakukan pemeriksaan status mental pada mahasiswa sebagai deteksi dini adanya gangguan mental. Minnesota Multiphasic Personality Inventory-2 (MMPI-2) adalah salah satu tes kesehatan mental seseorang yang berupa fungsi kepribadian, keadaan emosional saat ini dan sifat keparahan psikopatologi, serta dapat merumuskan intervensi atau pengobatan. ${ }^{9} \quad$ Supplementary Scales MMPI-2 merupakan salah satu dari beberapa skala MMPI-2 yang salah satunya menilai ketidakmampuan menyesuaikan diri yang terjadi pada mahasiswa. ${ }^{10}$ Salah satu kelebihan pada MMPI-2 yaitu didesain secara khusus untuk remaja dan dewasa. MMPI-2 di Indonesia telah diakui sebagai alat resmi diagnosa gangguan jiwa oleh psikiater. Alat ini telah lama diakui untuk mengukur fit and proper test oleh psikiater terhadap klien yang akan menuduki jabatan termasuk calon presiden. ${ }^{11}$

Mahasiswa semester 1 dipilih sebagai sampel karena cukup ideal untuk dijadikan objek penelitian mengingat mereka baru menyandang status sebagai mahasiswa. Bertolak dari berbagai hal yang telah diuraikan diatas maka penelitian ini 
Palempung, Kandou, Kairupan; Profil Supplementary Scales Minnesota Multiphasic...

dimaksudkan untuk melihat Supplementary Scales pada mahasiswa semester 1 tahun akademik 2013/2014 di Fakultas Kedokteran Universitas Sam Ratulangi Manado.

\section{METODOLOGI PENELITIAN}

Penelitian ini dilakukan dengan menggunakan metode deskriptif dengan melakukan survei cross sectional (potong lintang).Penelitian ini telah dilakukan dengan memberikan kuesioner kepada Mahasiswa Semester 1 Tahun Akademik 2013/2014 di Fakultas Kedokteran Universitas Sam Ratulangi Manado, dan dilaksanakan dalam periode bulan November 2013 - Januari 2014. Populasi adalah seluruh mahasiswa semester 1 dengan jumlah 259 orang, yang memenuhi kriteria inklusi (terdaftar sebagai mahasiswa semester 1 aktif kuliah yang bersedia menjadi responden juga berusia 18 tahun keatas) dan eksklusi (memiliki penyakit fisik yang berat juga tidak bisa hadir pada saat pengisian kuesioner) sebanyak 145 orang dan mahasiswa yang hadir mengikuti mengikuti tes MMPI-2 sebanyak 126 sedangkan hasil tes MMPI-2 yang valid sebanyak 101 orang.

Variabel dari penelitian ini yaitu supplementary scales, sosio-demografik (Jenis kelamin, umur, pekerjaan orang tua, asal daerah, jumlah saudara dan suku bangsa), profil akademik (Jalur masuk universitas, indeks prestasi SMA, modul yang tidak lulus pada saat ujian tengah semester).

Jenis dan cara pengambilan data yang didapatkan ialah primer dan sekunder, melalui tahap persiapan dan pelaksanaan. Dalam tahap pelaksanaanya kuesioner dibagikan kepada mahasiswa semester 1 disertai penjelasan mengenai tujuan dan manfaat pengumpulan data penelitian oleh ahli (dosen pembimbing). Selanjutnya, peneliti memberikan kesempatan kepada mahasiswa untuk bertanya hal-hal apa saja yang oleh mereka dianggap belum jelas. Waktu pemberian penjelasan dan menjawab pertanyaan sekitar 20 menit dan dijelaskan juga bahwa dijamin kerahasiaan datanya. Setelah itu kuesioner dibagikan kepada mahasiswa dengan waktu pengisian selama 90 menit. Setelah semua pertanyaan telah terisi jawaban, diberikan kesempatan selama 30 menit untuk memastikan kembali semua pertanyaan telah diisi dengan lengkap dan tepat. Setelah itu kuesioner dikumpulkan.

Data yang telah terkumpul tersebut diolah dan dianalisis melalui tahap editting, processing, cleanning, lalu dianalisis dengan menggunakan analisa univariat. Data supplementary scales MMPI-2 diserahkan pada pemeriksa untuk menginterpretasikan MMPI-2 yang diolah oleh program khusus. Untuk mengelola data sosio-demografi dan data hasil interpretasi MMPI-2 digunakan program Excel.

\section{HASIL PENELITIAN}

Terdapat 101 responden yang memiliki hasil valid. Data yang ditampilkan dibawah ini merupakan tiga skala yang memiliki nilai tertinggi pada supplementary scales MMPI2 pada mahasiswa semester 1 angkatan 2013/2014 FK UNSRAT dengan menggunakan cut off score $<50$ rendah, 5065 normal/rataa-rata, dan $>65$ tinggi.

Tabel 1. Distribusi mahasiswa berdasarkan jenis kelamin dan hasil tinggi pada Supplementary Scales

\begin{tabular}{ccccc}
\hline $\begin{array}{c}\text { Jenis } \\
\text { Kelamin }\end{array}$ & $\mathrm{N}$ & $\mathrm{A}$ & $\mathrm{Mt}$ & $\mathrm{PK}$ \\
\hline Laki-laki & 28 & 6 & 7 & 8 \\
& $27,7 \%$ & $5,9 \%$ & $6,9 \%$ & $7,9 \%$ \\
Perempuan & 73 & 16 & 19 & 13 \\
& $72,2 \%$ & $15,8 \%$ & $18,8 \%$ & $12,8 \%$ \\
TOTAL & 101 & 22 & 26 & 21 \\
& & $21,7 \%$ & $25,7 \%$ & $20,7 \%$ \\
\hline
\end{tabular}

Tabel 1 menunjukkan dari 101 hasil yang valid ditemukan 22 orang yang memiliki hasil yang tinggi pada skala Anxiety, terdiri dari 6 orang laki-laki dan 16 orang perempuan. Terdapat 26 orang yang memiliki hasil tinggi pada skala College Maldjusment, terdiri dari 7 orang laki-laki dan 10 orang perempuan, sedangkan skala Post Traumatic Stress Disorder Scales terdapat 21 orang memiliki hasil tinggi yang terdiri dari 8 orang laki-laki dan 13 orang perempuan. 
Tabel 2. Distribusi Mahasiswa Berdasarkan Asal Daerah dan Hasil Tinggi pada Supplementary Scales

\begin{tabular}{ccccc}
\hline $\begin{array}{c}\text { Asal } \\
\text { Daerah }\end{array}$ & $\mathrm{N}$ & $\mathrm{A}$ & $\mathrm{Mt}$ & $\mathrm{PK}$ \\
\hline SULUT & 65 & 17 & 20 & 17 \\
& $64,3 \%$ & $16,8 \%$ & $19,8 \%$ & $16,8 \%$ \\
Luar & 36 & 4 & 6 & 4 \\
SULUT & $35,6 \%$ & $3,9 \%$ & $5,9 \%$ & $3,9 \%$ \\
TOTAL & 101 & 21 & 26 & 21 \\
& & $20,7 \%$ & $25,74 \%$ & $20,7 \%$ \\
\hline
\end{tabular}

Tabel 3. Distribusi mahasiswa berdasarkan jumlah nilai ujian nasional SMA dan hasil tinggi pada Supplementary Scales

\begin{tabular}{ccccc}
\hline $\begin{array}{c}\text { Jalur } \\
\text { Masuk }\end{array}$ & $\mathrm{N}$ & $\mathrm{A}$ & $\mathrm{Mt}$ & $\mathrm{PK}$ \\
\hline Kurang & 18 & 7 & 8 & 7 \\
& $17,8 \%$ & $6,9 \%$ & $7,9 \%$ & $6,9 \%$ \\
Sedang & 30 & 4 & 6 & 3 \\
& $29,7 \%$ & $3,9 \%$ & $5,9 \%$ & $2,9 \%$ \\
Baik & 36 & 8 & 10 & 8 \\
& $35,6 \%$ & $7,9 \%$ & $9,9 \%$ & $7,9 \%$ \\
Sangat & 17 & 3 & 2 & 3 \\
Baik & $16,8 \%$ & $2,9 \%$ & $1,9 \%$ & $2,9 \%$ \\
TOTAL & 101 & 22 & 26 & 21 \\
& & $21,7 \%$ & $25,7 \%$ & $20,7 \%$ \\
\hline
\end{tabular}

Data tersebut menunjukkan dari 101 hasil yang valid ditemukan 21 orang yang memiliki hasil yang tinggi pada skala Anxiety, terdiri dari 17 orang yang berasal dari SULUT dan 4 orang dari luar SULUT. Terdapat 26 orang yang memiliki hasil tinggi pada skala College Maldjusment yang sebagian besar berasal dari SULUT dan hanya 4 orang yang berasal dari luar SULUT, sedangkan skala Post Traumatic Stress Disorder Scales terdapat 21 orang memiliki hasil tinggi pada skala ini yang terdiri dari 17 orang yang berasal dari SULUT dan 4 orang yang berasal dari luar SULUT.

Data tersebut menunjukkan dari 101 hasil yang valid ditemukan 22 orang yang memiliki hasil yang tinggi pada skala Anxiety, terdiri dari 7 orang yang memiliki nilai kurang $(<39,00), 4$ orang nilai sedang $(39,00-44,99), 8$ orang nilai baik $(45,00-$ $50,99)$ dan 17 orang nilai sangat baik $(>51,00)$. Terdapat 26 orang yang memiliki hasil tinggi pada skala College Maldjusment yang terdiri dari 8 orang nilai kurang, 6 orang nilai sedang, 10 orang nilai baik, dan 2 orang nilai sangat baik. Pada skala Post Traumatic Stress Disorder Scales terdapat 21 orang memiliki hasil tinggi pada skala ini yang terdiri dari 7 orang nilai kurang, 3 orang nilai sedang, 8 orang nilai baik dan 3 orang nilai sangat baik.

Tabel 4. Distribusi Mahasiswa Berdasarkan Banyaknya Modul yang Tidak Lulus pada Ujian Tengah Semester dan Hasil Tinggi pada Supplementary Scales

\begin{tabular}{ccccc}
\hline $\begin{array}{c}\text { Modul } \\
\text { yang } \\
\text { tidak }\end{array}$ & $\mathrm{N}$ & $\mathrm{A}$ & $\mathrm{Mt}$ & $\mathrm{PK}$ \\
lulus & & & & \\
\hline 0 & & & & \\
& 71 & 16 & 20 & 14 \\
1 & $70,2 \%$ & $15,8 \%$ & $19,8 \%$ & $13,8 \%$ \\
& 18 & 2 & 2 & 3 \\
2 & $17,8 \%$ & $1,98 \%$ & $1,9 \%$ & $2,9 \%$ \\
& 11 & 4 & 4 & 4 \\
\multirow{2}{*}{3} & $10,8 \%$ & $3,9 \%$ & $3,9 \%$ & $3,9 \%$ \\
& 1 & 0 & 0 & 0 \\
TOTAL & $0,9 \%$ & $0 \%$ & $0 \%$ & $0 \%$ \\
& $\mathbf{1 0 1}$ & $\mathbf{2 2}$ & $\mathbf{2 6}$ & $\mathbf{2 1}$ \\
\hline
\end{tabular}

Data tersebut menunjukkan dari 101 hasil yang valid ditemukan 22 orang yang memiliki hasil yang tinggi pada skala Anxiety, terdiri dari 16 orang yang memiliki modul lulus semua, 2 orang memiliki 1 modul tidak lulus, 4 orang memiliki 2 modul tidak lulus, dan tidak ada yang memiliki 3 modul yang tidak lulus. Terdapat 26 orang yang memiliki hasil tinggi pada skala College Maldjusment yang sebagian besar memiliki modul yang lulus semua, 2 orang memiliki 1 modul yang tidak lulus, 4 orang yang memiliki 2 modul yang tidak lulus, dan tidak ada yang memiliki 3 modul yang tidak lulus. Pada skala Post Traumatic Stress Disorder Scales terdapat 21 orang memiliki hasil tinggi pada skala ini yang terdiri dari 14 orang memiliki modul yang lulus semua, 3 orang memiliki 1 modul yang tidak lulus, 4 orang yang memiliki 2 modul yang tidak lulus, dan seperti pada skala yang lain, tidak ada yang memiliki 3 modul yang tidak lulus. 
Palempung, Kandou, Kairupan; Profil Supplementary Scales Minnesota Multiphasic...

\section{BAHASAN}

Berikut adalah pembahasan mengenai tiga supplementary scales yang memiliki hasil paling tinggi.

\section{Anxiety (A)}

Pada penelitian ini didapatkan 22 responden yang memiliki psikopatologi Anxiety yang tinggi. Tingginya skor dari skala ini mengindikasikan orang yang neurotik (terlalu gelisah), tidak mampu menyesuaikan diri, over kontrol, dan cenderung memiliki sejarah sebelumnya dengan perawatan kesehatan mental. Sedangkan skor yang rendah mengindikasikan orang mampu beradaptasi, lancar berbicara, dan percaya diri. Pada penelitian sebelumnya yang dilakukan pada semester 5 tahun akademik 2012/2013 Fakultas Kedokteran UNSRAT Manado dengan jumlah sampel sebesar 100 orang didapatkan mahasiswa tidak mengalami kecemasan tingkat rendah (17\%), normal (64\%), dan yang rendah $(19 \%){ }^{12}$

\section{College Maladjustment (Mt)}

Dari 101 responden penelitian terdapat 26 responden yang memiliki skor yang tinggi pada skala ini. Tingginya skor pada skala ini mengindikasikan individu yang memiliki kemampuan adaptasi psikologik yang kurang, merasa tidak berguna dan pesimistik. Hanya terdapat 1 responden yang memiliki skor rendah, bila dibandingkan dengan penelitian yang sebelumnya terdapat 18 responden yang memiliki skor yang rendah ${ }^{12}$ Rendahnya skor pada skala ini mengindikasikan individu yang tidak cemas dan memiliki kemampuan adaptasi yang bagus.

\section{Post Traumatic Stress Disorder (PK)}

Dari 101 responden penelitian ini didapatkan 20,79\% yang mendapat skor tinggi. Hal ini mengindikasikan individu memiliki kecemasan, gangguan emosi yang terus-menerus, gangguan tidur, pikiran yang terganggu dan yang tidak dikehendaki. Sedangkan skor rendah mengindikasikan individu yang mampu beradaptasi dan tidak cemas. Terdapat 1,9\% responden yang memiliki skor rendah pada skala ini, bila dibandingkan dengan penelitian yang sebelumnya yang dilakukan oleh Pretty Sitorus, terdapat 17 responden mendapat skor tinggi dan 22 responden yang memiliki skor rendah pada skor ini. ${ }^{12}$

\section{SIMPULAN}

Dari penelitian ini dapat diketahui 3 skala supplementary scales tertinggi adalah Anxiety (21,78\%), College Maldjusment (25,74\%), dan Post Traumatic Stress Disorder (20,79\%). Pada penelitian ini pula dapat diketahu persentase terbanyak dari responden yang memiliki hasil tinggi pada ketiga skala supplementary scales adalah yang berjenis kelamin perempuan (72,2\%), berasal dari Sulut (64,3\%), jumlah nilai UN baik (35,6\%), dan memiliki modul yang lulus semua pada ujian tengah semester (70,2\%).

\section{DAFTAR PUSTAKA}

1. Hidayat DR. Permasalahan Mahasiswa. Jakarta: Universitas Negeri Jakarta; c2011 [cited 2012 Oct 21]. Available from: http://www.kopertis3.or.id/html/wpcontent/uploads/2011/04/permasalahanmahasiswa-2.pdf.

2. Papalia, DE, Old, SW, \&Feldman, RD. Human Development. New York: Mc Graw Hill. 2009. Hal 119

3. Kaplan HI, Saddock BJ. Grebb JA. Sinopsis Psikiatri. Jilid I. Jakarta: Binarupa Aksara; 2010:406-12.

4. Gunarsa S. D. Dari Anak Sampai Usia Lanjut: Bunga Rampai Psikologi Anak. Jakarta: PT BPK Gunung Mulia. 2004. Hal 87-92.

5. Nurdianiah F. Profil Ketrampilan Menjalin Relasi Pertemanan Mahasiswa [skripsi]. Bandung: Universitas Pendidikan Indonesia; 2010.

6. Hidayat D. Penggunaan Metode Dua Menit (M2M) dalam Menentukan Prevalensi Gangguan Jiwa di Pelayanan Primer [jurnal]. Jakarta: Universitas Kristen Krida Wacana; 2010.

7. Devi S. Doctor in distress. World Report. 2011 [cited Nov 2012] 377:454-55. Available from: www.thelancet.com 
8. Center of Public Mental Health. Faculty of Psychology Universitas Gajah Mada; 2012. Available from: http://cpmh.psikologi. ugm.ac.id/?page_id=261

9. Ganellen RJ. Integrating the rorschach and the MMPI-2 in personality assesment. In: Weiner IB, editor. Personality and clinical psychology series. New Jersey: Lawrence Elrbraum Associated; 1996. p. 1-2.

10. Graham JR. MMPI-2. Assesing personality and psychopatology. 4th Ed. New York: Oxford University Press; 2006. P. 114-51.
11. Anonymous. Tentang MMPI. Diunduh dari: http.//psikometrika.com/mmpi-mmpi-2/.

12. Sitorus P. Profil Supplementary Scales Minnesota Multiphasic Personality Inventory-2 (MMPI-2) Adaptasi Indonesia pada mahasiswa semester5 Tahun Akademik 2012/2013 Fakultas Kedokteran Universitas Sam Ratulangi Manado [skripsi]. Manado: Universitas Sam Ratulangi; 2013. 